\title{
KIEMELTEN TEHETSÉGES GYERMEKEK, TANULÓK GONDOZÁSA A BORSOD-ABAÚJ-ZEMPLÉN MEGYEI PEDAGÓGIAI SZAKSZOLGÁLATBAN
}

\section{Szerző:}

Kopasz Gáborné

B-A-Z Megyei Pedagógiai Szakszolgálat

Cigándi Tagintézménye

A Szerző e-mail címe:

kopasznebea@gmail.com

\section{Lektorok:}

Estefánné Varga Magdolna (Ph.D.)

Eszterházy Károly Egyetem

Mező Katalin (Ph.D.)

Debreceni Egyetem

és további két anonim lektor...

\begin{abstract}
Absztrakt
A tanulmány célja, hogy bemutassa a pedagógiai szakszolgálatokban megvalósítható tehetséggondozó munkát, annak lehetőségeit és korlátait valamint a szakszolgálati intézményrendszer előnyeit és hátrányait. A kutatás megyei szintű feltárás eredménye, mely a Borsod-Abaúj-Zemplén Megyei Pedagógiai Szakszolgálat valamennyi tagintézményében folyó tehetséggondozó munkát mutatja be.
\end{abstract}

Kulcsszavak: tehetség, tehetséggondozás, pedagógiai szakszolgálat

Diszciplina: pedagógia, gyógypedagógia

\begin{abstract}
CARING FOR HIGHLY GIFTED CHILDREN AND STUDENTS IN PEDAGOGICAL SERVICES

The aim of the study is to present the talent development work that can be implemented in pedagogical professional services, its possibilities and limitations, as well as the advantages and disadvantages of the institutional system of professional services. The research is the result of a county-level exploration, which presents the talent management work in all member institutions of the Borsod-Abaúj-Zemplén County Pedagogical Service.
\end{abstract}

Keywords: talent, talent management, pedagogical professional service

Disciplines: pedagogy, special education Kopasz Gáborné (2021): Kiemelten tehetséges gyerekek, tanulók gondozása a BorsodAbaúj-Zemplén Megyei Pedagógiai Szakszolgálatokban. OxIPO - interdiszciplináris tudományos folyóirat, 2021/1, 99-109. doi: 10.35405/OXIPO.2021.1.99 
A tanulmány a Borsod-Abaúj-Zemplén Megyei Pedagógiai Szakszolgálat tagintézményeiben folyó tehetséggondozó munka bemutatásáról szól, különös tekintettel a Cigándi Tagintézményre. A megyei szintű kutatás oka, hogy viszonylag fiatal szakterület ez a szakszolgálatokban, így a kép nagyon változatos mintázatot mutathat az ellátás szintjeit, mélységét és tartalmát illetően. A korábban térségi, kistérségi szinten működő pedagógiai szakszolgálatok 2013-ban szerveződtek megyei szintű intézménnyé, melynek minden járásban van egy-egy tagintézménye. A pedagógiai szakszolgálatok köznevelési feladatot ellátó intézmények, melyek 9 szakfeladatot látnak el, ezek közül egyik, a kiemelten tehetséges gyermekek és tanúlók gondozása. Azért érdemes figyelmet fordítani a témára, mert 2013 elôtt rendkívül kevés szakszolgálat látott el tehetséggondozással kapcsolatos feladatot. Ezt követően kötelező szakfeladatként egyre több tagintézmény szervezte meg az ellátást, mára pedig már minden egyes tagintézmény rendelkezik tehetséggondozó koordinátorral, akik járási szinten koordinálják az illetékességi területükhöz tartozó nevelési-oktatási intézmények tehetséggondozó tevékenységét, segítik, támogatják a tehetséggondozó szakemberek munkáját, valamint járási és megyei szintű hálózatot működtetnek.

\section{A tehetség fogalma}

A tehetséget sokan, sokféleképpen megfogalmazták már. Jelenleg hazánkban a legelfogadottabb a Renzulli-féle tehetségmeghatározás, melyet lényegében a köznevelési törvény is használ az alábbi formában: „Kiemelten tehetséges gyermek, tanuló: az a különleges bánásmódot igénylő gyermek, tanuló, aki átlag feletti általános vagy speciális képességek birtokában magas fokú kreativitással rendelkezik, és felkelthető benne a feladat iránti erős motiváció, elkötelezettség." (2011. évti törvény a Nemzeti Köznevelésről 4.S 14., megj.: a továbiakban e törvényre az NKt. rövidítéssel történik utalás).

$\mathrm{Az}$ átlag feletti általános képességek mellett a speciális képességeknek több féle fajtája van, melyek a Gardneri csoportosítás alapján a következők: nyelvi, zenei, matematikai-logikai, vizuális-téri, testi-mozgásos, interperszonális, intraperszonális.

A kreativitás többek között a jó problémamegoldó képességet, rugalmas gondolkodást foglalja magában. A kreatív gyermek ötletgazdag, az új, vagy váratlan helyzetekben is jól feltalálja magát.

A feladat iránti elkötelezettséget pedig a kitartás, a versenyszellem, a tartós érdeklődés jellemzi (v.ö.: Balogh, 2007).

\section{A hazai tehetséggondozás jogi háttere}

A tehetséggondozás múködése jelenleg Magyarországon jól szabályozott, melynek a hatályos törvények, rendeletek adnak keretet. A pedagógiai szakszolgálati tevékenység múködését, illetve az abban 
folyó tehetséggondozással kapcsolatos munkát az alábbi rendelkezések határozzák meg.

A pedagógiai szakszolgálat - mint köznevelési intézmény - működését meghatározó jogszabályok:

- 2011. évi CXC. törvény a Nemzeti Köznevelésről

- 20/2012. (VIII. 31.) EMMI rendelet a nevelési-oktatási intézmények működéséről és a köznevelési intézmények névhasználatáról

- 15/2013. (II. 26.) EMMI rendelet a pedagógiai szakszolgálati intézmények múködéséről

A pedagógiai szakszolgálatokra vonatkozó paragrafusok pedig a következők:

Mnt korábban említettük, a kiemelten tehetséges gyermek, tanuló fogalmát a nemzeti köznevelésről szóló 2011. évi CXC. törvény 4.S 14. pontja határozza meg. Szakszolgálati feladat, hogy e meghatározást figyelembe véve, segítse a nevelési-oktatási intézményekben megtalálni a kiemelten tehetséges gyermekeket, tanulókat, a rendelkezésre álló szakemberek és speciális diagnosztikai eszközök segítségével.

A köznevelési törvény 18.』-a alapján ,a szülő és a pedagógus nevelő munkáját, valamint a nevelési-oktatási intézmény feladatainak ellátását pedagógiai szakszolgálat segíti” (Nkt. 18.S (1)).

A pedagógiai szakszolgálatok feladatai:

- „gyógypedagógiai tanácsadás, korai fejlesztés és gondozás,
- szakértői bizottsági tevékenység,

- a nevelési tanácsadás,

- a logopédiai ellátás,

- a továbbtanulási, pályaválasztási tanácsadás,

- a konduktív pedagógiai ellátás,

- a gyógytestnevelés,

- az iskolapszichológiai, óvodapszichológiai ellátás,

- a kiemelten tehetséges gyermekek, tanulók gondozása". (Nkt. 18.』 (2))

A pedagógiai szakszolgálatoknak tehát kötelező alapfeladata a kiemelten tehetséges gyermekek, tanulók gondozása, melynek kereteit a 15/2013. (II.26.) EMMI rendelet határozza meg.

A nevelési-oktatási intézmények működéséről és a köznevelési intézmények névhasználatáról szóló 20/2012. (VIII. 31.) EMMI rendelet 132.S (3) bekezdés és annak e) pontja pedig kimondja, hogy ,az óvodapszichológus, az iskolapszichológus a nevelési-oktatási intézményben a gyermekekkel, a tanulókkal közvetlenül, egyéni vagy csoportos foglalkozások keretében közremúködik (...) a kiemelten tehetséges gyermek, tanuló tehetséggondozásában, és a pedagógusokkal és a pedagógiai szakszolgálat szakemberével közösen kidolgozza az együttmúködés és az ellátás kereteit".

A Borsod-Abaúj-Zemplén Megyei Pedagógiai Szakszolgálat Cigándi Tagintézménye - illetékességi területe a Cigándi Járás, ahol 22 nevelési-oktatási intézmény található, ebből 11 óvoda és 11 általános 
iskola. Egyetlen nevelési-oktatási intézményben sincs óvoda-, vagy iskolapszichológus, így a 15/2013. EMMI rendelet értelmében az óvoda-, iskolapszichológiai feladatokat a szakszolgálat pszichológusa látja el.

A pedagógiai szakszolgálati intézmények múködéséről szóló 15/2013. (II. 26.) EMMI rendeletben, több szakterületen is megjelenik a tehetséges gyermekek segítése.

A tehetség felismerése tehát nyilvánvalóan nem csak a kiemelten tehetséges gyermekek, tanulók gondozása szakterületen dolgozó szakemberek feladata és felelőssége.

A rendelet 24. S-a értelmében ,az Intézmény nevelési tanácsadás feladatának keretében ellátásban részesülők esetében, segítséget nyújt a gyermek családi-, és óvodai neveléséhez, a tanuló iskolai neveléséhez és oktatásához, ha a gyermek, tanuló egyéni adottsága, fejlettsége, képessége, tehetsége, fejlődésének üteme indokolja” (15/2013. (II.26.) EMMI r. 24.S (1) b)).

A pedagógiai szakszolgálat szakemberei tehát nevelési tanácsadás keretében segítséget nyújtanak a tehetséges gyermekek oktatásához, neveléséhez. Természetesen a tanácsadás az ellátásban részesülő gyermekek számára vehető igénybe ezen a területen, amennyiben a szülő, és/vagy a pedagógus igényli azt.

A szakszolgálati rendelet 26.』-a alapján „a továbbtanulási, pályaválasztási tanácsadás feladata a tanuló adottságainak, tanulási képességének, irányultságának szakszerű vizsgálata, és ennek eredményeképpen iskolaválasztás ajánlása. A tanácsadás során figyelembe kell venni a tanuló személyes adottságait és érdeklődését. A továbbtanulási, pályaválasztási tanácsadás keretében nyújtott tájékoztatás elősegíti a tanuló pályaválasztását, figyelembe véve az egyéni tulajdonságokat és a foglalkoztatási lehetőségeket, ennek érdekében kapcsolatot tart a foglalkoztatási pályaválasztási tanácsadóval, valamint a tehetséggondozó hálózattal” (15/2013. (II.26.) EMMI r. 26.§(1)-(2)).

A továbbtanulási, pályaválasztási tanácsadás a megyei pedagógiai szakszolgálat feladata, azt a járási szakszolgálatok nem tarthatnak, de az ellátás igénybevételének elősegítése érdekében kapcsolatot tartanak a megyei pedagógiai szakszolgálat pályaválasztási tanácsadójával, akik a gyermek tehetségének figyelembe vételével ajánlanak továbbtanulási lehetőséget, megfelelő iskolatípust, esetleg konkrét intézményt.

A rendelet 30.』-a szól a kiemelten tehetséges gyermekek, tanulók gondozásáról, miszerint az intézmény feladata a kiemelten tehetséges gyermekek, tanulók gondozása keretében:

1) A korai tehetség-felismerés, tehetségazonosítás, amelynek során a tehetség életkori megjelenését figyelembe kell venni. A korai tehetség-felismerés, tehetség-azonosítás érdekében tehetségfejlesztő szakemberünk az intézmények kérésére, a szülők beleegyezésével tanév eleji 
szűrést végez, melynek eredményeire alapozva az intézmények lebonyolítják a beválogatást, a megfelelő tehetségműhelybe. Ezen a téren azonban rendkívül fontos a szakértői bizottság munkája is, ahol a komplex diagnosztika módszere nagyban hozzásegít a tehetség felismeréséhez. Számtalanszor tapasztaljuk, hogy a hiperaktív tünetekkel, vagy tanulási zavar tüneteivel hozzánk küldött gyermekekben már az intelligencia vizsgálat során megmutatkozik a tehetség egyik ismérve, a magas, sokszor szórt intelligencia. A gyógypedagógiai vizsgálat során pedig felfedezhető egy-egy kiemelkedő teljesítmény akár nyelvi, akár vizuális, vagy matematika területén. Ilyen esetben a diagnosztikai munkánk alkalmával a tehetséggondozásra is javaslatot teszünk a szükséges fejlesztések mellett.

2) A tehetséges gyermek személyiségfejlődésének támogatása, szükség esetén további megsegítésre irányítás. A személyiségfejlődés támogatása céljából személyiségfejlesztő csoportot indíthatunk, melyet tehetséggondozó szakterületen végzett pedagógus is tarthat.

3) Önismereti csoport szervezése és vezetése a tehetséges gyermekek részére. Az önismereti csoport szervezése és vezetése a pszichológus kompetenciakörébe tartozik, mely szintén elősegíti a tehetség kibontakozását, a megfelelő önismeret, és az egészséges önbizalom kialakítása által.

4) Tanácsadás, támogatás a szülőnek. Amint az már fentebb is olvasható volt, ez nem csupán a tehetséggondozó peda- gógus, de a pszichológus, a gyógypedagógus, a fejlesztőpedagógus feladata is és más szakterületeken is megjelenik.

5) Konzultáció a pedagógus részére. Szakembereink már a tanév eleji szűrést követően is biztosítanak konzultációs lehetőséget a pedagógusok és a szülők részére, ahol a szűrési eredményekről történő tájékoztatás része a gyengébb teljesítmény mellett a tehetségesnek mutatkozó terület kiemelése is, valamint a gondozás lehetôségeinek számba vétele.

6) Közös tehetség-tanácsadási fórum szervezése. Illetékességi területünkön minden településen egyetlen óvoda és általános iskola van, középfokú intézmény pedig nem működik. Így nem könnyű a tehetségek számára tanácsadást, fórumot tartani, vagy javaslatot tenni. Az a cél, hogy a gyermek, tanuló saját intézményében részesüljön olyan szolgáltatásban, mely a tehetségét támogatja, még ha csupán szakkör formájában van is arra lehetőség. Nem múködik minden intézményben tehetségmúhely, de ahol van rá mód, ott a tanórán kívüli tevékenységekbe beépítik a tehetséggondozást. Arra nincs lehetőség, hogy a szülő más településre elvigye gyermekét egy-egy múhely céljából, mert ezt az itt élő családok anyagi helyzete nem teszi lehetővé, és az átjárhatóság sem biztosított. Ugyanakkor a sportegyesülethez bátran küldhetünk gyerekeket, mivel ők megoldják a szállítást és az edzéseket is iskolaidő után tartják. 
7) Speciális tehetségprogramban való részvételre javaslat adása. Környékünkön Kisvárdán és Sárospatakon múködik Arany János tehetséggondozó program, ahová minden éven több diák is bejut a Bodrogközból.

8) A tehetségazonosítás. A tehetséggondozás feladatát ellátó pszichológus szakmai kapcsolatot tart a feladatellátási körzetében múködő tehetségfejlesztő programok vezetőivel és az iskolapszichológussal, óvodapszichológussal. A térségben nincs óvoda-, iskolapszichológus, de minden nevelési-oktatái intézményben, illetve valamennyi tehetséggondozással foglalkozó partnerintézményben van kijelölt kapcsolattartó, akikkel rendszeres a kommunikáció.

9) Javaslatot tesz a tanuló számára a tehetségprogramba történő bekapcsolódásra. Az Arany János Tehetségprogramba való bekapcsolódásra javaslatot tehetünk, mivel a környéken több olyan gimnázium is múködik, ahol az említett tehetségprogram alapján folyik az oktatás.

10) Kimeneti mérések elvégzése. Az intézmények kérésére szakembereink beés kimeneti méréseket is végeznek, melyek eredményeit felhasználják a saját specifikus szűrésük kiegészítésére.

11) Tehetségfejlesztő műhelyek vezetői számára konzultációs lehetőség biztosítása, melyet a tehetséggondozó koordinátor lát el. A tehetséggondozó koordinátorok rendszeres kapcsolatot tartanak a nevelési-oktatási intézmények intézmé- nyekben dolgozó pedagógusokkal. Többek között múhelymunkát szervezhetnek, ahol az intézmények megismerhetik egymás tehetséggondozó munkáját, bemutathatják tehetségprogramjukat és beszámolhatnak sikereikről. (15/2013. (II.26.) EMMI r. 30.S (1))

A tehetséggondozó koordinátor szintén a szakszolgálati rendelet 30.\$-a alapján:

- „kapcsolatot tart a nevelési-oktatási intézmények iskolapszichológusaival, óvodapszichológusaival,

- kapcsolatot tart a Nemzeti Tehetségponttal,

- ismeri, figyelemmel kíséri a Nemzeti Tehetségügyi Adatbázist,

- ismeri, figyelemmel kíséri a Nemzeti Tehetség Program pályázati kiírásait,

- kapcsolatot tart a Nemzeti Tehetségfejlesztési Központtal” (15/2013. (II.26.) EMMI r. 30.§ (2)).

Intézményünk tehetséggondozó koordinátorai figyelemmel követik a pályázati lehetőségeket, melyekre rendszerint felhívják az intézmények figyelmét. Szükség szerint segítik, támogatják a nevelési-oktatási intézmények tehetséggondozó munkáját. Igény szerint segítik az intézményt a tehetséggondozó program elkészítésében, a tehetségműhely beindításában, a beválogatásban. Együttmúködhetnek egyéb, nem oktatási jellegű, tehetséggondozást végző intézményekkel, civil szervezetekkel, mint pl. az alapfokú múvészeti iskolák, vagy a sportegyesületek. Tehet- 
ségkoordinációval kapcsolatban lásd még: Mező (2012).

\section{Helyzetkép}

A helyzetkép összeállítása során a Borsod-Abaúj-Zemplén Megyei Pedagógiai Szakszolgálat 16 tagintézményeinek vezetőitől történt adatgyűjtés egy 11 kérdésből álló kérdőív révén.

Vizsgálatunk kiterjedt a tehetség-gondozó tevékenység tartalmára a különböző tagintézményekben (1. ábra).

Az 1. ábrából látható, hogy a tagintézmények 31,3\%-a csak koordinációt végez, 6,3\%-uk csak szűrést végez, és a nevelésioktatási intézmény oldja meg a gondozást. Ezekben az iskolákban/óvodákban tehát feltehetően van megfelelő pedagógus a gondozáshoz, csupán a beválogatáshoz kérik a szakszolgálat szakemberének segítségét. Ezzel szemben 25\% gondoz csak óvodás gyermekeket, $6,3 \%$ pedig csak iskolás tanulókat. Ennek a nagy különbségnek az az oka, hogy az óvodákba könnyebben bejutnak a szakszolgálat szakemberei a tehetséggondozó tevékenységgel, és azt az óvodák a délelőtti órákban szívesen fogadják.

Az iskolák esetében más a helyzet, hiszen tanítási időben nem mehetnek a szakemberek, a délutáni órákban azonban további iskolai programokkal halmozzák el a tanulókat. Ahol tehát tudják, megoldják iskolai keretek között, vagy nem igényelnek ellátást. 31,3\% azonban mindkét intéz-ménytípusba be tud jutni tehetséggon-dozási tevékenységgel, mely elég nagy arány a fent leírtak tükrében.

1. ábra: A tehetséggondozó tevékenység tartalma (forrás: a Szerzô).

\section{Foglalkozik-e a tagintézmény tehetséggondozással?}

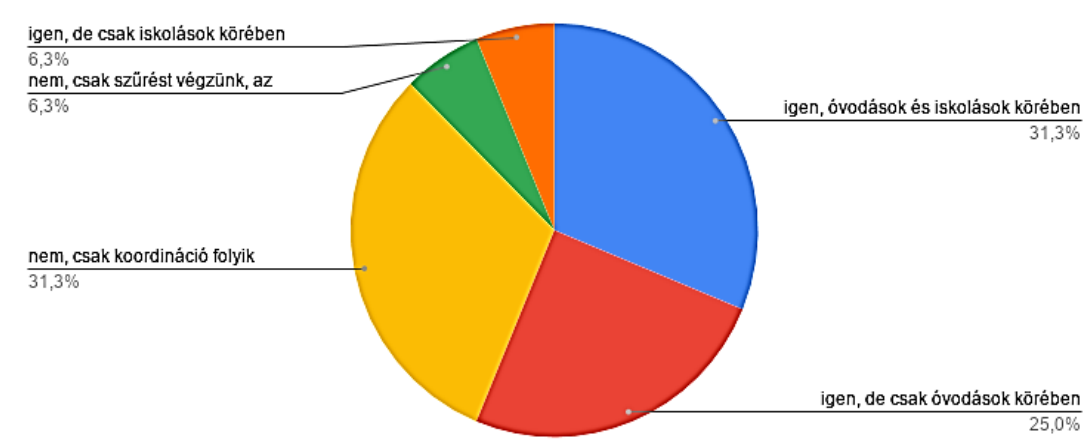


Ez nem azt jelenti, hogy ezekben az intézményekben nem megoldott iskolai/óvodai keretek között a gondozás, lehetséges, hogy olyan tehetséggondozó programmal tudja a szakszolgálat megkínálni az intézményeket, melyet kihasználva bővül a nevelési-oktatási intézmény tevékenységköre. Így van ez a Cigándi tagintézményben is, ahol az interperszonális tehetséggondozó foglalkozások sikeresen működnek. A továbbiakban összevetettük az illetékességi terület nagyságával az intézményben dolgozó szakemberek számát, melyből következtethetünk arra, hogy a kapacitások hogyan alakulnak az intézményben (2. ábra).

A 2. ábra szemlélteti, hogy van, ahol nagyon kevés szakember jut az ellátandó intézményekre. Ez természetesen meghatározza a kapacitásokat. Ezért érdemes azt is megnézni, hogy ebből a szakemberállományból hány fő dolgozik a tehetséggondozás szakfeladaton.

Vannak a szakfeladatot, kiemelkedő heti óraszámmal működtető tagintézmények, és vannak, akik csupán heti 1-2 órát tudnak szánni a feladatra, az illetékességi terület méretétôl függetlenül (3. ábra). Feltételezhető, hogy utóbbiak többnyire azok, akik csak koordinációt látnak el. Itt fontos megemlíteni, hogy a Cigándi Tagintézményben az aktuális igényekhez igazítva, heti 10-21 órában működik a tehetséggondozás. A heti óraszámok mellett fontos ismernünk az ellátottak számát is, hiszen az óraszámok nem tükrözik az ellátotti létszámot, mivel nem egységesen maghatározott a koordinációra szánt óra sem.

2. ábra: Az illetékességi terület és a szakember ellátottság összefüggései (forrás: a Szerző).

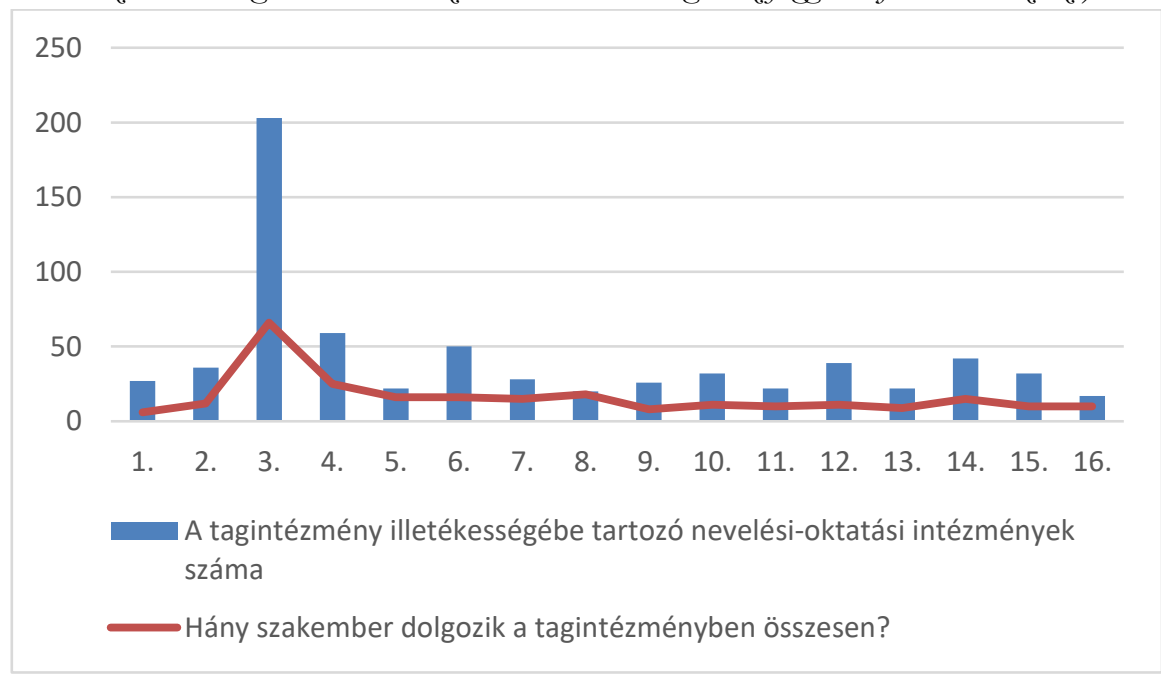


3. ábra: A sqakemberállomány és a sqakfeladaton dolgozó szakemberek sqámának összefüggései (forrás: a Szerző́).

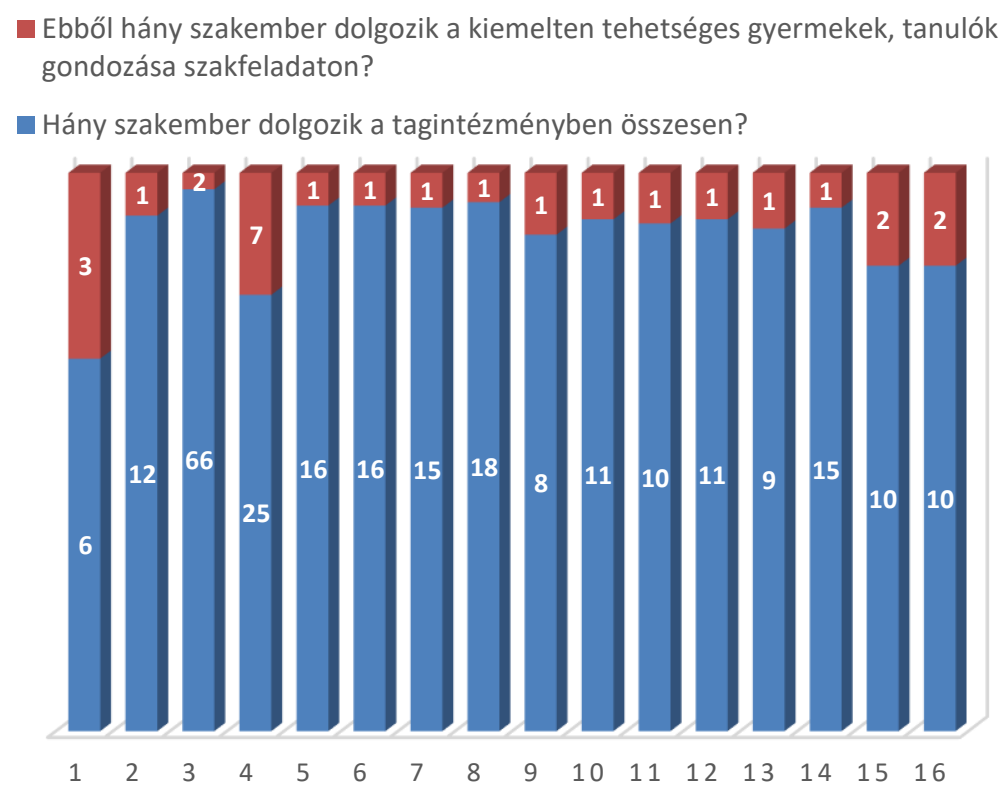

Az ellátotti létszám szintén rendkívüli szórást mutat. 6 intézményben egyáltalán nem működik gondozás, csak koordináció. Ebből egy szakszolgálat elvégzi a szűréseket, de az iskolák/óvodák rendelkezésére bocsájtja annak eredményeit. 10 tagintézmény végez gondozást, akik változó gyereklétszámmal dolgoznak, és csupán a tagintézmények fele biztosítja óvodás és iskolás gyermekek számára is a feladatot. A fennmaradó 5 tagintézményből 4-ben csak óvodás és a maradék 1 tagintézményben pedig csak iskolás gyermekeket látnak el.
Emellett azt is vizsgáltuk, hogy milyen az intézményvezetők, a pedagógusok és a szülők hozzáállása a tehetséggondozás szakfeladathoz. A tagintézmény-igazgatók nagy része úgy gondolja, hogy a pedagógusok többsége nyitott, (25\% szerint kiváló, 56,3\% szerint pedig megfelelő a kapcsolat ezen a téren) a szülők pedig együttmúködést tanúsítanak a tehetséggondozó tevékenység során. Ellenben a vezetők 12,5\%-a úgy véli, hogy a pedagógusok csak részben fogadják el a tehetséggondozást a szakszolgálattól, 6,3\%-uk szerint pedig kifejezetten elutasítják ezt a tevékenységünket. A szülők 
pedig a vezetők 25\%-a szerint közömbösek, 12,5\% pedig azt gondolja, hogy nem ismerik el tehetséggondozó tevékenységünket és nem ismerik fel a tehetséget gyermekükben, így nem is támogatják annak kibontakoztatását. Ezek az utóbbi számadatok elég lesújtóak. Mégpedig azért, mert ha összesítjük a pedagógusok részéről a részben megfelelőnek és a nem megfelelőnek ítélt hozzáállást az közel 20\%. A szülők közömbössége és elutasító magatartása pedig közelít a 40\%-hoz.

\section{Megvitatás}

Bebizonyosodott, hogy a megye 16 tagintézményében valóban nagyon eltérő képet mutat a tehetséggondozó tevékenység, annak tartalmát és a gondozottak számát illetően is. Az ellátásban felmerülő hiányosságokat nem a szakemberhiány, hanem a szakfeladatok közötti óraelosztás okozza, hiszen az igényeket nem, vagy csak részben kielégíteni tudó tagintézmények 70\%-ában ez akadályozza az ellátás kiszélesítését.

A kapcsolatok vizsgálata során az került felszínre, hogy sajnos a pedagógusok és a szülők befogadása valóban nehezített még ezen a fiatalnak mondható szakfeladaton. $\mathrm{A} z$ intézmények valóban úgy ítélik meg, hogy elvesszük tőlük a lehetőséget, a szülők pedig nem tartják fontosnak a gyermekükben rejlő tehetség kibontakoztatását, melynek fő oka a családok szociokulturális háttere és a szülők iskolázatlansága.

\section{Korlátozások}

A szakszolgálati tehetséggondozás múködtetésében, a Cigándi Tagintézmény vonatkozásában, több probléma is felfedezhető. Elsősorban a szakemberhiány okozza a legnagyobb nehézséget. Másodsorban pedig az, hogy ha van uyan megfelelő szakember, de más szakfeladat ellátásában van rá szükség. Intézményünkben ez nagymértékben tapasztalható. Hiszen vannak olyan szakfeladatok, melyek ellátása prioritást kell, hogy élvezzenek, mint például a korai fejlesztés, vagy a szakértői bizottsági tevékenység.

Problémákat okoz továbbá a kidolgozatlan jogszabályi háttér, mely nem teszi számunkra egyértelművé, hogy a tehetséggondozás, mint szakfeladat milyen formában, és milyen tartalommal foglalja magában a valódi gondozási tevékenységet, így a jogi szabályozók különböző értelmezései nem feltétlenül teremtenek egységességet sem megyei, sem országos szinten.

$\mathrm{Az}$ egyenlőtlenség megyei szinten is jelentős, mely azt eredményezi, hogy míg az egyik járásban élő gyermek megkapja az ellátást, addig a másik járásban élő nem. Mindemellett járáson belül is érzékelhető a különbség ugyanezen elvek alapján, vagyis míg az egyik intézmény diákja hozzájut a tehetséggondozó ellátáshoz, addig a másik intézmény tanulója nem, tehát az átjárhatóság sem biztosított.

Végül pedig arról sem szabad megfeledkeznünk, hogy milyen a nevelésioktatási intézmények vezetőivel, pedagó- 
gusaival és a szülőkkel való kapcsolat, mely nagymértékben befolyásolja a szakmai munkát. Egy „fiatalabb” szakfeladat tekintetében minden esetben nehezebb elfogadtatni magunkat a partnereinkkel és idő kell hozzá, míg nyitottá és együttműködővé válnak.

A problémák megoldását az egyértelműen kidolgozott jogszabályi háttér segítené elő, valamint a szakemberállomány bővítése és a szakfeladatok egyenértékű kezelése. Sajnos tisztában vagyunk vele, hogy nem lehet egységességet teremteni, sem országos, sem megyei, sem járási szinten. A települések és az intézmények közötti különbségek meghatározzák, és egyben korlátozzák is ennek a lehetőségét. Ugyanakkor tudunk törekedni ezeknek az egyenlőtlenségeknek a minimalizálására, bizonyos alapelvek meghatározásával. Fontos továbbá a partnerekkel való jó kapcsolat kialakítása és erősítése, a bizalom elnyerése.

\section{Irodalom}

15/2013. (II. 26.) EMMI rendelet a pedagógiai szakszolgálati intézmények müködéséröl
2011. évi CXC. törvény a nemzeti köznevelésröl 20/2012. (VIII. 31.) EMMI rendelet a nevelési-oktatási intézmények müködéséröl és a köznevelési intézmények névhasználatáról

Balogh, L (2007). Elméleti kiindulási pontok tehetséggondozó programokhoz - A Nemzeti Balogh, L. (2016). Az egyéni tehetségfejlesztő programok alapjai. Didakt kiadó, Debrecen.

Tehetségsegítő Tanács 2007. január 5-6-i tanácskozásához

Csíkszentmihályi, M (2010). Tehetséges gyerekek. Nyitott könyvmúhely, Budapest.

Mező Ferenc (Szerk.)(2012): Tehetségkoordinátorok kézikönyve. $\mathrm{K}+\mathrm{F}$ Stúdió $\mathrm{Kft}$. Debrecen.

Nagy Jenőné (2012). Tehetségigéretek gondozásának elmélete és gyakorlata.

Tóth, L. (2013). A tehetséggondozás és kutatás története. Didakt kiadó, Debrecen.

Net1:

http://okt.ektf.hu/data/szlahorek/file /kezek/03_david_04_15/822tehetsgm odellek.html 